\title{
The Crime of Witchcraft and Vigilante Action (Eigenrichting)
}

\author{
Syamsuddin ${ }^{*}$, Ridwan ${ }^{* *}$ and Iksan ${ }^{* * *}$ ) \\ *) Sekolah Tinggi Ilmu Hukum Muhammadiyah Bima, E-mail: \\ syamsuddinbima59@gmail.com \\ **) Sekolah Tinggi Ilmu Hukum Muhammadiyah Bima, E-mail: sahecapi13@gmail.com \\ ${ }^{* * *}$ S Sekolah Tinggi Ilmu Hukum Muhammadiyah Bima, E-mail: iksan687@gmail.com
}

\begin{tabular}{|c|c|}
\hline Article & Abstract. \\
\hline $\begin{array}{l}\text { Keywords: } \\
\text { Action; Crime; Vigilante; } \\
\text { Witchcraft. } \\
\text { Article History } \\
\text { Received: 2021-11-05; } \\
\text { Reviewed: 2021-11-22; } \\
\text { Accepted: 2021-11-22; } \\
\text { Published: 2021-11-24. } \\
\text { DOI: } \\
\underline{\text { http://dx.doi.org/10.3065 }} \\
\text { /jdh.v4i4.17951 }\end{array}$ & $\begin{array}{l}\text { The witchcraft incident in Bima Regency has threatened the safety } \\
\text { and security of human life, witchcraft has triggered people to take } \\
\text { vigilante actions (Eigenrichting) as a counter reaction by means of } \\
\text { destruction, persecution and even murder. This study aims to de- } \\
\text { termine public perceptions related to witchcraft, and also to find } \\
\text { out why witchcraft always results in mass vigilante action (Eigen- } \\
\text { richting) so that prevention and resolution efforts can be formu- } \\
\text { lated. This study uses empirical or sociological research, data col- } \\
\text { lection is carried out by direct and structured interviews and } \\
\text { through literature study, while drawing conclusions using inductive } \\
\text { methods. The results showed, first; In the period 2016-2021, there } \\
\text { were } 53 \text { cases of alleged witchcraft practices in Bima Regency, } \\
\text { damaging the social order and disrupting community stability. The } \\
\text { community considers witchcraft as a dangerous or evil act, be- } \\
\text { cause the motive and purpose of using witchcraft is to torture, } \\
\text { and/or kill human souls; Second; The behavior of witchcraft has led } \\
\text { to vigilante actions (Eigenrichting) in some people, this is due to } \\
\text { the existence of a legal vacuum that has not regulated the act of } \\
\text { witchcraft and how to solve it legally. The act of vigilantism (Eigen- } \\
\text { richting) appears as a form of reaction that arises from the com- } \\
\text { munity due to their rights and comfort being disturbed, which ac- } \\
\text { tion is manifested in the form of violence as an act of revenge } \\
\text { against the perpetrators of witchcraft. The juridical conclusion that } \\
\text { the terminology of witchcraft and vigilante acts (Eigenrichting) } \\
\text { have not been specifically regulated in the current laws and regu- } \\
\text { lations as prohibited acts and are threatened with punishment. As } \\
\text { a suggestion that the terminology and elements of the criminal act } \\
\text { of witchcraft in the current Criminal Code Bill need to be expanded } \\
\text { further, as well as the system of proving the crime of witchcraft in } \\
\text { the Indonesian criminal procedure law needs to obtain further, } \\
\text { more complete arrangements. }\end{array}$ \\
\hline
\end{tabular}

(C)2021; This is an Open Access Research distributed under the term of the Creative Commons Attribution License (https://Creativecommons.org/licences/by/4.0), which permits unrestricted use, distribution, and reproduction in any medium, provided the original works is properly cited

\section{Introduction}

In general, Indonesian people consider witchcraft to be synonymous with disgraceful acts that can threaten the safety of human life. The term witchcraft itself in 
the Big Indonesian Dictionary is equated with magic ${ }^{1}$ or in other terms it is also called black magic, in Javanese belief this black magic can harm humans. Witchcraft is a negative energy that can damage a person's life in the form of illness, household destruction to death ${ }^{2}$. In general, witchcraft is believed to be an act that can cause pain to cause death to a person, because of that, witchcraft is also widely opposed in Indonesian society. In practice, witchcraft is carried out by shamans/owners of black magic or psychics to harm others remotely by using several methods and tools such as needles, dolls, shrouds, which are believed to be very effective. As a result, someone who is exposed to witchcraft or black magic will experience pain to the point of death. Although witchcraft has long been considered a danger to humans or viewed as a crime against humans,

The phenomenon of witchcraft in Bima Regency often occurs and has greatly disturbed the community, whenever there is an alleged witchcraft act, the community tends to judge suspected witchcraft by means of violence in the form of burning houses, persecution, and even murder. The data obtained by the author, from 2016 to 2021 there were at least 53 (fifty three) cases of alleged crimes of witchcraft, almost all of which were not legally resolved through law enforcement agencies because the law does not regulate it as a crime or criminal act. $^{3}$ The incident was experienced by a Wadukopa resident, Bima-NTB Regency, Haji Pasa, a suspected perpetrator of witchcraft/magic crimes, was judged by the community by being burned alive by the local community, then in 2021 a person named Pakoh, a resident of Kawuwu Village, Langgudu District, Bima Regency, was hacked by the community because he was accused of being a witch doctor. ${ }^{4}$

The void of legal norms in the form of laws and regulations relating to witchcraft has led to vigilante behavior among the Bima community which is contrary to the prevailing laws and regulations. In a criminological perspective, vigilante action (Eigenrichting) itself is a reaction that arises from the community, both as individuals and in the form of groups due to their rights and comfort being disturbed by actions/deeds that harm both materially and immaterially, which are concretely manifested in the form of violence as an act of revenge. ${ }^{5}$ The act of vigilantism (Eigenrichting) itself is seen as an effective solution when the means of resolving state law are dull and can no longer be used to try and settle concrete cases that are seen as very disturbing to the public.

Facing a legal vacuum and preventing vigilante action (Eigenrichting), the government has actually attempted to criminalize witchcraft, which has been formulated in Article 293 Paragraph (1) of the Draft Criminal Code, it is explained that

\footnotetext{
${ }^{1}$ https://kbbi.web.id/santet. accessed on June 10, 2021

${ }^{2}$ Herniti, E. 2015. Kepercayaan Masyarakat Jawa Terhadap Santet, Wangsit, Dan Roh Menurut Perspektif Edwards Evans-Pritchard. ThaqÃfiyỹ̃T, 13(2), 384-400. http://ejournal.uinsuka.ac.id/adab/thaqafiyyat/article/view/77

${ }^{3}$ Analyzed based on the results of interviews with a number of sources/respondents from 19 to April 2021

4 https://regional.kompas.com/read/2021/02/10/17545531/diduga-dukun-santet-kakek-dan-nenek-inidibacok-sekumpul-orang-rumah?page=all accessed on 20 June 2021

${ }^{5}$ Hendrawati, H., \& Krisnan, J. 2019. Main Hakim Sendiri (Eigenrichting) Dalam Perspektif Kriminologis. Proceeding of The URECOL, Proceeding of The 10th University Research Colloquium. Bidang Pendidikan, Humaniora dan Agama, 31-38.
} 
"everyone who claims to have the power unseen, informs, gives hope, offers, or provides assistance services to others that because his actions can cause illness, death, or mental or physical suffering, a person is sentenced to a maximum imprisonment of 5 years or a maximum fine of Category IV. ${ }^{6}$ However, the pros and cons regarding the formulation of the witchcraft offense in the Draft Criminal Code Bill are still hotly debated by legal experts in the country, causing the delay in the ratification of the Criminal Code Bill until now.

This study aims to determine the perspective of the people of Bima Regency regarding witchcraft, and also to find out the reasons why people take vigilante actions (Eigenrichting) in punishing witchcraft so that it can formulate prevention and resolution efforts. This research is considered important considering that research on witchcraft and the act of playing alone in Bima Regency has never been done by previous researchers.

\section{Research Methods}

This research uses empirical or sociological research, namely legal research that functions to see the law in real terms and also examines how the law works in society. ${ }^{7}$ Data collection techniques were carried out through direct and structured interviews with perpetrators and victims of witchcraft, traditional/community leaders, village heads and law enforcement officers (police investigators) and also through literature studies. The data obtained from the interviews were then confirmed with library data to test their suitability with the theoretical basis, principles, and applicable legal norms. While drawing conclusions using the inductive method, namely drawing conclusions that depart from empirical and specific facts, then general conclusions can be drawn.

\section{Results and Discussion}

\subsection{Community Perspectives About Witchcraft in Bima Regency}

The term witchcraft is a term known in the East Javanese tradition, while in the traditions of the West Java and Banten communities it is known as teluh, ganggoang, and sogna, while the Central Javanese people call it tenun. In addition, in the tradition of the Sumatran community, it is called biring or tinggam, begu ganjang, while the Balinese people call it desti, teluh, atau tenang jana. Papua is called Suangi, Minahasa is called Pandot. ${ }^{8}$ In the tradition of the Bima people it is known as santet, sihir, or gunaguna.

According to Edi S. Ekadjati in the book The Secret of Witchcraft (2010) that witchcraft or other known terms is a legacy of the past several centuries ago that continues to survive in the lives of Indonesian people until now. ${ }^{9}$ Likewise, in the

\footnotetext{
${ }^{6}$ See, Elucidation of Article 239 paragraph (1) of the Draft Law on the Criminal Code

7 Irwansyah. 2020. Penelitian Hukum: Pilihan Metode \& Praktik Penulisan Artikel, Revision Edition. Yogyakarta: Mirra Buana Media. p. 21

${ }^{8}$ A.Masruri, (2010). The Secret of Santet. Jakarta: Visimedia. p. 2

${ }^{9}$ Ibid., p. 2
} 
tradition of the Bima people, they consider witchcraft or magic to have existed since time immemorial which is still alive and continues to be practiced by some people until now. From 2016 to 2021, allegations of witchcraft have occurred in several villages and sub-districts of Bima Regency, some of which can be seen in the table below.

Table 3.1.1

Data on Witchcraft in Bima Regency

From 2016 to 2021

\begin{tabular}{|c|c|c|c|c|c|c|}
\hline \multirow[t]{2}{*}{ No } & \multirow[t]{2}{*}{ village } & \multirow{2}{*}{$\begin{array}{c}\text { Numbe } \\
r \text { of } \\
\text { Cases }\end{array}$} & \multicolumn{2}{|c|}{ Perpetrator } & \multicolumn{2}{|c|}{ Impact on Victims } \\
\hline & & & Is known & Not known & $\begin{array}{c}\text { Sick/ } \\
\text { Healed }\end{array}$ & Dead \\
\hline 1. & Parangina & 2 & 0 & 2 & 0 & 2 \\
\hline 2. & Soro & 16 & 4 & 12 & 10 & 6 \\
\hline 3. & Melayu & 3 & 2 & 1 & 2 & 1 \\
\hline 4. & Kawuwu & 3 & 3 & 0 & 3 & 0 \\
\hline 5. & Mawu & 1 & 1 & 0 & 1 & 0 \\
\hline 6. & Soromandi & 1 & 1 & 0 & 0 & 1 \\
\hline 7. & Lanta & 2 & 1 & 1 & 1 & 1 \\
\hline 8. & Kaleo & 12 & 5 & 7 & 5 & 7 \\
\hline 9. & Monta Baru & 1 & 0 & 1 & 0 & 1 \\
\hline 10. & Sari & 12 & 2 & 10 & 7 & 5 \\
\hline Amc & ount & 53 & 19 & 34 & 29 & 24 \\
\hline
\end{tabular}

Source. Processed from various sources.

Based on table 1 (one) above, from 2016 to 2021, the phenomenon/behavior of witchcraft in Bima Regency is very high. A total of 53 victims of alleged witchcraft, of which 19 people are suspected of being the perpetrators, 34 people are not known to be. While the victims, 29 people experienced serious illness and recovered, and 24 people died due to suspicion of being exposed to witchcraft with certain characteristics. Based on the results of the author's interview with Ashar $\mathrm{H}$. Abdul Hamid as the Head of Parangina Village, Sape District, Bima Regency, that witchcraft behavior is an act that is considered detrimental to the community, because witchcraft behavior is related to the use of occult sciences that can harm or injure a person's life. ${ }^{10}$

According to Ismail Sulaiman, one of the religious leaders and the Imam of the Mosque, Sape District, admitted that he knows very well and can even recognize the characteristics of people as perpetrators of witchcraft. According to him, the sign or characteristic of a person due to witchcraft is if a person gets sick suddenly and at certain times, for example at night until late in the morning, while in the morning until the afternoon the condition is normal or suddenly falls unnaturally ill, this condition is common in slowly feeling like being blown by the wind on the tips of the toes and fingers and gradually getting worse, marked by the body feels stiff, heavy and difficult to move or the stomach suddenly swells are the characteristics of people who have been subjected to witchcraft. ${ }^{11}$ In reality, the pain that arises or is caused by the behavior of

\footnotetext{
${ }^{10}$ Interview with MrAshar H. Abdul Hamid, April 09, 2021; o'clock. 10.15 WIT.

${ }^{11}$ Interview with youlsmail Sulaiman, April 12, 2021; 4:00 p.m
} 
witchcraft cannot be treated medically, and can only be treated by certain people who have special knowledge. ${ }^{12}$ Furthermore, Ismail Sulaiman, explained that his treatment was through the provision of drinking water that had previously been filled or read a prayer according to religious teachings, so at once the perpetrators of witchcraft through the victim admitted and explained the reasons for witchcraft against the victim, but sometimes they could not be treated so that concerned died. Meanwhile, $\mathrm{H}$. Nasrudin explained that witchcraft is the behavior of a person using magical powers remotely, through an intermediary of goods or objects that are planted/stored in the yard or certain place with the intention that the person experiences pain and even dies. $^{13}$

From the various opinions stated above, that the practice of witchcraft is carried out by certain people, such as shamans who have supernatural skills and powers. In the Indonesian Dictionary, a shaman is defined as a person whose job is to treat, give incantations, spells, witchcraft, and etc. ${ }^{14}$ The practice of witchcraft is done by inserting objects or something to another person's body unseen (assisted by jinn and demons) with the aim of damaging the welfare of others or harming, animate and inanimate objects are influenced and controlled in certain ways ${ }^{15}$. The main motive or purpose of the behavior of witchcraft is intended to bring pain or death to the intended person, so the purpose of its use is to hurt and harm others.

If viewed from the motive and purpose of using witchcraft, this act is indeed an evil act so that it must be avoided and prevention is carried out, regarding evil deeds or crimes according to R. Soesilo include all human behavior even though it has not been / is not specified in the law, but the act by community perceived or interpreted as behavior or actions that economically or psychologically attack and injure moral feelings in common life. ${ }^{16}$

Even though it is felt or considered evil by the community, but until now the Indonesian criminal law has not stipulated the act of witchcraft as an act that is prohibited and threatened with criminality, this condition is indeed very difficult for law enforcement officers who tend to view crime normatively legalistically as limited to actions specified in the law. In the perspective of criminal law, actually the essence of criminal law is intended to maintain order and provide peace by prohibiting every act of disturbing/injuring property or human life. Because the act of witchcraft has been considered a crime that can harm others, it can actually be categorized as a criminal act. In line with this, Sudarto explained that criminal acts or In other terms, it is known as a criminal act, which is an act that fulfills certain conditions, is carried out by a person, which allows the provision of a crime ${ }^{17}$ This kind of act can be referred to as an act that can be punished or abbreviated as an evil act in a sociological/social sense.

\footnotetext{
12 Ibid.

${ }^{13}$ Interview with you H. Nasaruddin, April 10, 2021, at 17.00 WITA.

${ }^{14}$ Nurdin, A. 2012. Komunikasi Magis Dukun (Studi Fenomenologi Tentang Kompetensi Komunikasi Dukun). Jurnal ASPIKOM, 1(5), 383. https://doi.org/10.24329/aspikom.v1i5.43

${ }^{15}$ Falikhah, N. (2012). Santet dan Antropologi Agama. Alhadharah: Jurnal Ilmu Dakwah, 11(22), 129-138.

${ }^{16}$ Saleh Muliadi, (2012). Aspek Kriminologis Dalam Penanggulangan Kejahatan. Fiat Justitia Jurnal IImu Hukum Volume 6 No. 1 January-April 2012,

${ }^{17}$ Sudarto. 1986. Hukum Pidana 1. Bandung: Alumni. p. 70
} 
In this regard, Mulyatno explained that for a criminal act to exist, the following elements must be met; a). Human actions; b). Those who meet the formulation in the law (formal requirements); and, c). Is against the law (material requirements) ${ }^{18}$. What is meant by human actions are actions carried out by humans as legal subjects in the sense of being active (doing/doing something) or passive (not doing/not doing something), while fulfilling the formulation of the law means an active act (doing/doing something) or passive (not doing/not doing something) has been formulated as an act that is prohibited or ordered by law accompanied by a criminal threat. While the element is against the law, according to the author requires 2 (two) things; firstly against the law formally with regard to the absence of justification as regulated in Articles 45-49 of the Criminal Code, secondly; materially against the law.

\subsection{Witchcraft and vigilante acts (Eigenrichting) or en masse in Bima Regency}

As previously explained, people view witchcraft as an evil act and harm others, therefore witchcraft is more widely opposed by the community. Everyone who practices witchcraft is considered to have committed a crime, however, in the laws and regulations in the criminal field, it seems that the act that is considered evil and detrimental to the community is an evil act in the law. The absence of legal norms in the form of laws and regulations related to witchcraft cases has created legal turmoil and uncertainty for the Indonesian people. Legal uncertainty regarding the mechanism for solving the crime of witchcraft that has disturbed residents and disturbed the stability of society, especially in Bima Regency.

Several alleged incidents of witchcraft so far have triggered conflicts between communities as the alleged perpetrators, victims and other communities and the occurrences are repeated every year. Based on M. Sidik's statement as the Secretary of Kawuwu Village, Bima Regency, the people who were directly affected by the witchcraft incident tended to take vigilante actions by killing the alleged perpetrator and burning his residence, as a result of this incident the community was restless and experienced fear. ${ }^{19}$ Then this incident became viral in various mass media / print "An elderly husband and wife in Kawuwu Village, Langgudu District, Bima, West Nusa Tenggara (NTB), was rushed to the hospital after being stabbed by a group of people, the mob also burned the house of the husband and wife. According to information, the cause of the incident was because the victims had long been suspected of being the perpetrators of witchcraft in the local village ${ }^{20}$.

According to M. Sidik, the main witchcraft incident in Kawuwu Village was very often carried out by certain individuals, several cases had been reported by the community to the Village Government and the local Police Station to be resolved legally. However, neither the village government nor the police could follow up on it because there is no law (law) that regulates it and it is difficult to prove it legally. Likewise, for the witchcraft incident in Mawu Village, Ambalawi District, Bima Regency, the alleged perpetrator of the witchcraft crime was judged by the community by burning the house,

\footnotetext{
${ }^{18}$ Ibid., p. 71

19 Interview with Mr. M. Sidik, April 24, 2021, at 11.30 WITA.

20 https://regional.kompas.com/read/2021/02/10/17545531/diduga-dukun-santet-kakek-dan-nenek-inidibacok-sekumpul-orang-rumah?page=all accessed on 20 June 2021
} 
and the perpetrator himself was killed by the community. ${ }^{21}$ Almost the same as the incident in Wadukopa Village, Soromandi District, Bima Regency, the suspected perpetrator of the crime of witchcraft, a married couple burned their house and their husband was burned alive by the local community. ${ }^{22}$.

The results of the author's research show that almost all cases of witchcraft in Bima Regency tend to be resolved by means of violence, murder and arson or the community responds by taking action on their own. Data on vigilante actions due to witchcraft events in Bima Regency can be seen in the table below:

Table 3.2.2

Data on Witchcraft and Judicial Actions

In Bima Regency from 2016 to 2021.

\begin{tabular}{|c|c|c|c|c|c|c|}
\hline \multirow[t]{3}{*}{ Year } & \multirow{3}{*}{$\begin{array}{l}\text { Number } \\
\text { of Cases }\end{array}$} & \multicolumn{5}{|c|}{ Solution } \\
\hline & & \multicolumn{2}{|c|}{ Report Police } & \multicolumn{3}{|c|}{ Society (Judicial Action) } \\
\hline & & Report & $\begin{array}{l}\text { Not } \\
\text { Report }\end{array}$ & destruction & Persecution & Murder \\
\hline 2016 & 9 & 0 & 9 & 7 & 1 & 1 \\
\hline 2017 & 9 & 0 & 9 & 6 & 2 & 1 \\
\hline 2018 & 10 & 0 & 10 & 4 & 4 & 2 \\
\hline 2019 & 9 & 0 & 9 & 7 & 1 & 1 \\
\hline 2020 & 9 & 0 & 9 & 7 & 1 & 1 \\
\hline 2021 & 7 & 0 & 7 & 3 & 2 & 2 \\
\hline $\begin{array}{l}\text { Amou } \\
\text { nt }\end{array}$ & 53 & 0 & 53 & 34 & 11 & 8 \\
\hline
\end{tabular}

Source. Processed from various sources.

In the number of cases above, it seems that not a single case has ever been reported or resolved through the mechanism of state law (police), the community tends to solve it by taking vigilante action against suspected witchcraft perpetrators, as many as 34 cases by destroying/burning houses, as many as 11 abuses and murder as many as 8 cases. According to Ashar H. Abdul Hamid as the Head of Parangina Village, Sape Subdistrict, Bima Regency, every time there is witchcraft behavior, it must cause turmoil from the community to take vigilante action. The action was taken as a reaction from the community who were afraid of the practice of witchcraft which was considered to be the victim, the community found out for themselves the culprit then immediately reacted by gathering families and the community at large to attack the alleged witchcraft ${ }^{23}$.

Based on an interview with Quraisin as the Sape Police of Bima Regency, that if the witchcraft case was reported to the police, surely the police would have difficulty following up reports or complaints from the public regarding the alleged crime of witchcraft, this is because the law has not regulated it at all, as well as the proof which is considered difficult can not even be proven legally. The police can only take preventive

\footnotetext{
${ }^{21}$ Interview with Mr. Syukriadin, dated, April 16, 2021, at. $10.00 \mathrm{am}$.

${ }^{22}$ Interview with Mr. Ardin, April 18, 2021, at. 14.00 WITA.

${ }^{23}$ Interview with Quraisin, date, 09 April 2021; O'clock. 10.15 WIT.
} 
or preventive measures through appeals, invitations to be resolved by family deliberation involving the role of community leaders and local religious leaders, so as not to cause turmoil in the community, however, the community continues to take vigilante actions by burning, ${ }^{24}$. Quraisin added, on the one hand the crime of witchcraft is true and can threaten the stability of society, while on the other hand law enforcement cannot prosecute the act because the law does not regulate it as a prohibited act and is threatened with punishment.

According to Suherman $\mathrm{H}$. Yusuf as the Head of Criminal Investigation Unit of the Sape and Lambu District Police, Bima Regency, there is a dilemmatic position in dealing with the black magic incident in the Bima Regency community. The same thing was also conveyed by Rus, am as Kapolsek in the Legal Territory of Lambu District, Bima Regency. Based on interviews that he admitted that he often received complaints from the public regarding the problem of witchcraft crimes, his party had problems in starting investigations and investigations. This condition is caused by an inadequate juridical basis in the form of laws governing the crime of witchcraft ${ }^{25}$. According to Rus'am, the void of legal norms governing the crime of witchcraft is the cause of the community, especially the victims to take vigilante actions which he considers as a fair solution, in the form of destroying houses to murder. ${ }^{26}$. TThe act of vigilantism (Eigenrichting) is a reaction from the community, both as individuals and groups as a result of their rights and comfort being disturbed by actions that harm them, which is concretely manifested in the form of violence as an act of revenge. ${ }^{27}$ In various cases it is considered commensurate with the actions of the perpetrators of witchcraft that have disturbed the community.

According to the author himself, both witchcraft and witchcraftvigilantism (Eigenrichting) are both despicable acts and also deviate from human moral values. Same with witchcraft, that tvigilantism (Eigenrichting) also actually not specifically regulated in criminal law regulations in Indonesia. ${ }^{28} \mathrm{So}$ far, the perpetrators of acts of vigilantism are only subject to certain articles, for example; Article 406 of the Criminal Code on vandalism, Article 170 of the Criminal Code on violence with collective labor, Article 351 of the Criminal Code on Persecution, Article 338 and Article 340 on Murder, and so on. ${ }^{29}$ Thus, both witchcraft and witchcraftvigilantism (Eigenrichting) in the future need to be regulated in a clear and firm formulation in the applicable laws and regulations so that there is a vacuum of legal norms to prosecute these two types of actions.

Based on the information (information and statements as well as data) obtained by the author during the research, the act of playing alone (Eigenrichting) as a recompense for witchcraft is caused by 3 (three) factors, including; First, the factor of

\footnotetext{
24 ibid

${ }^{25}$ Interview with Mr. Suherman Yusuf, April 12, 2021, at. $10.00 \mathrm{am}$.

${ }^{26}$ Interview with Mr. Rus'am, Monday, April 12, 2021 at. 09.00 am.

${ }^{27}$ Hendrawati, H., \& Krisnan, J. 2019. Main Hakim Sendiri (Eigenrichting) Dalam Perspektif Kriminologis. Proceeding of The URECOL, Proceeding of The 10th University Research Colloquium 2019: Bidang Pendidikan, Humaniora dan Agama, 31-38.

${ }^{28}$ I Gusti Agung Kiddy Krsna Zulkarnain. 2019. Kriminalisasi perbuatan main hakim sendiri (eigenrichting) dalam hukum pidana di indonesia. Kertha Wicara, 1-17

${ }^{29}$ Interview, Rus'am, Monday, April 12, 2021 at. 09.00 am.
} 
the community itself which tends to be restless and anarchic in responding whenever there is witchcraft behavior; Second, related legal factors have not criminalized the act of witchcraft as a crime in the law, thus creating legal uncertainty; Third, the factor of proving witchcraft is indeed difficult, considering that this act uses the power of supernatural beings. These three factors are factors that cause vigilante action (Eigenrichting) carried out by the people of Bima Regency in responding to witchcraft behavior.

Considering that witchcraft has been seen as a crime that has disturbed the community and has triggered social conflict, of course, ways to overcome it are needed so that people are protected in their lives. In criminal law, crime prevention or what is known as criminal politics according to Marc Ancel as The National organization of the control of crime by society or Sudarto briefly explains it as a rational effort of the community in tackling crime. ${ }^{30}$ Regarding this matter, Sudarto further explained that criminal policy, in a narrow sense is a reaction to law violations in the form of crime, while in a broad sense it is a function of law enforcement officials in order to uphold legal justice, including the workings of the police and courts, even In the broadest sense, according to him quoted from Jorgen Jespen, criminal policy is the entire policy taken through legislation and official bodies that aim to enforce the norms of society. ${ }^{31}$.

The mechanism for overcoming crime, especially the crime of witchcraft, theoretically and implementatively, can at least be done through non-penal and penal means. Non-penal means are related to the efforts of the community and law enforcement officers in providing views, knowledge, awareness to the public about witchcraft behavior and other consequences (losses) arising from such behavior, while the use of penal facilities is to determine or criminalize witchcraft as a prohibited act and are threatened with criminal laws and regulations, and also use law enforcement institutions and officials (police, prosecutors, and courts) as agencies/officials who try and impose crimes, thus taking vigilante action(Eigenrichting) society can end.

\section{Conclusion}

The practice of witchcraft is seen by the community as a very evil act, disturbing comfort and harming other people in the midst of community life. The motive and purpose of using witchcraft is intended to injure and take people's lives by using supernatural/demon powers. Meanwhile, vigilante action (Eigenrichting) is a public reaction that rejects the behavior of witchcraft, as an act of retribution (punishment) that is commensurate and fair to the perpetrators of witchcraft, due to the existence of a legal vacuum (laws and regulations) that regulate the act of witchcraft. In order to minimize vigilante actions (Eigenrichting) in prosecuting/punishing perpetrators of witchcraft, it is necessary to ratify the Criminal Code Bill which is currently being discussed in the DPR by expanding the understanding and elements of the crime of witchcraft not only to "people who declare, notify/offer assistance/services of witchcraft to others" but also include "people who use it for their own purposes and purposes". Besides that, in the Draft Criminal Procedure Code, it is necessary to regulate

\footnotetext{
${ }^{30}$ Barda Nawawi Arief. 2002. Bunga Rampai Kebijakan Hukum Pidana. Jakarta: PT. Citra Aditya Bakti. p. 65

${ }^{31}$ Ibid., p. 67
} 
the procedures for proving the crime of witchcraft/occult in the Indonesian criminal law enforcement system.

5. Reference

Journals:

[1] Falikhah, N. (2012). Santet dan Antropologi Agama. Alhadharah: Jurnal Ilmu Dakwah, 11(22), 129-138. https://jurnal.uinantasari.ac.id/index.php/alhadharah/article/view/1777

[2] Hendrawati, H., \& Krisnan, J. (2019). Main Hakim Sendiri (Eigenrichting) Dalam Perspektif Kriminologis. Proceeding of The URECOL, Proceeding of The 10th University Research Colloquium. Bidang Pendidikan, Humaniora dan Agama, 3138. http://repository.urecol.org/index.php/proceeding/article/view/637

[3] Herniti, E. (2015). Kepercayaan Masyarakat Jawa Terhadap Santet, Wangsit, Dan Roh Menurut Perspektif Edwards Evans-Pritchard. ThaqÃfiyyÃT, 13(2), 384-400. http://ejournal.uin-suka.ac.id/adab/thaqafiyyat/article/view/77

[4] I Gusti Agung Kiddy Krsna Zulkarnain. (2019). Kriminalisasi perbuatan main hakim sendiri (eigenrichting) dalam hukum pidana di indonesia. Kertha Wicara, 1-17. https://ojs.unud.ac.id/index.php/kerthawicara/article/view/54434

[5] Nurdin, A. (2012). Komunikasi Magis Dukun (Studi Fenomenologi Tentang Kompetensi Komunikasi Dukun). Jurnal ASPIKOM, 1(5), 383. https://doi.org/10.24329/aspikom.v1i5.43

[6] Saleh Muliadi, (2012). Aspek Kriminologis Dalam Penanggulangan Kejahatan. Fiat Justitia Jurnal Ilmu Hukum Volume 6 No. 1 Januari-April. https://www.google.com/search?q=Saleh+Muliadi\%2C+\%282012\%29.+Aspek+Kr iminologis+Dalam+Penanggulangan+Kejahatan.+Fiat+Justitia+Jurnal+Ilmu+Huku $\mathrm{m}+$ Volume+6+No.+1

\section{Books:}

[1] A.Masruri. 2010. The Secret of Santet, Jakarta: Visimedia. ISBN: 9790650752

[2] Barda Nawawi Arief. 2002. Bunga Rampai Kebijakan Hukum Pidana, Jakarta: PT. Citra Aditya Bakti. ISBN: 9789791486460

[3] Irwansyah. 2020. Penelitian Hukum: Pilihan Metode \& Praktik Penulisan Artikel. Edisi Revisi. Yogyakarta: Mirra Buana Media. ISBN: 9786236571804.

[4] Sudarto. 1986. Hukum Pidana 1. Bandung: Alumni. ISBN: 979-414-245-X

\section{Internet:}

[1] https://kbbi.web.id/santet accessed on 10 June 2021

[2] Kompas. (2021). diduga-dukun-santet-kakek-dan-nenek-ini-dibacok-sekelompokorang-rumahnya. Accessed on 20 June 2021.

\section{Interview:}

[1] Interview with Mr. Abdul Hadi Abdullah, Head of Soro Village in Bima, April 18, 2021, at. 14.00 WITA. 
[2] Interview with Mr. Ardin, Soromandi Community in Bima, April 18, 2021, at. 14.00 WITA.

[3] Interview with Mr Ashar H. Abdul Hamid, Head of Parangina Village in Bima, April 09, 2021; o'clock. 10.15 WIT.

[4] Interview with you $\mathrm{H}$. Nasaruddin, Religious Leader in Bima, April 10, 2021, at 17.00 WITA.

[5] Interview with Ismail Sulaiman, religious/customary leader in Bima, April 12, 2021; 4:00 p.m

[6] Interview with Mr. M. Sidik, Bima, Secretary of Kawuwu Village in Bima, April 24, 2021, at 11.30 WITA.

[7] Interview with Quraisin, Head of the Sape District Police Bhima, date, 09 April 2021; O'clock. 10.15 WIT.

[8] Interview with Mr. Rus'am,Lambu District Police Chief in Bima, date, April 12, 2021 at. $09.00 \mathrm{am}$.

[9] Interview with Mr. Suherman Yusuf, Head of Criminal Investigation Unit of the Sape Police in Bima, April 12, 2021, at. 10.00 am.

[10] Interview with Mr. Syukriadin, Mawu Village Community in Bima, April 16, 2021, at. $10.00 \mathrm{am}$.

\section{Regulations:}

[1] Act No. 1 of 1946 concerning the Criminal Code

[2] Act No. 8 of 1981 concerning the Criminal Procedure Code

[3] Draft Law on Indonesian Criminal Code (RUU KUHP) 